DOI: $10.15690 /$ vramn584

А.А. Калошин, Е.И. Леонова, А.В. Солдатенкова, Н.А. Михайлова

НИИ вакцин и сывороток им. И.И. Мечникова, Москва, Российская Федерация

Исследование протективных свойств рекомбинантного комплекса

белка F наружной мембраны и анатоксина Pseudomonas aeruginosa

Pseudomonas aeruginosa вызывает осложнения после ожогов, травм и хирургических вмешательств, являясь одной из основных причин нозокомиальных инфекций. Этот патоген обладает высокой резистентностью к большинству антибактериальных средств, поэтому иммунопрофилактика рассматривается как один из приоритетных подходов для борьбы с синегнойной инфекцией. Цель исследования: изучить защитные свойства рекомбинантного комплекса белка F наружной мембраны (OprF) и атоксической формы экзотоксина A (анатоксина) от экспериментальной синегнойной инфекции. Методы. Рекомбинантные белки, содержащие дополнительную шестигистидиновую последовательность, синтезировали в клетках Escherichia coli с помощью изопропил- $\beta$ - $d$-тиогалактопиранозида и очищали методом аффинной хроматографии с использованием Ni-сефарозы. Внутрибрюшинно иммунизировали мышей препаратами рекомбинантных белков. В качестве адбюванта использовали гидроксид алюминия. Экспериментальное заражение осуществляли внутрибрюшинным введением живой вирулентной культуры Р. аетиgіпова штамма РА103. Результаты. При двукратной иммунизации мышей комплексом, содержащим 25 мкг OprF и 50 мкг анатоксина, выявлен наилучший протективный эффект (индекс эффективности защитных свойств в этом случае составил 4,0). Индексы эффективности для рекомбинантных белков, вводимых двукратно в тех же дозах по отдельности, соответствовали 2,0 для ОрrF и 2,3 для анатоксина и не увеличивались после трехкратной иммунизации животных. Уменьшение в два раза доз (12,5 мкг OprF и 25 мкг анатоксина) при трехкратном введении способствовало увеличению выживаемости мышей, иммунизированных отдельными белками (индексы эффективности - 3 для ОргF и 3,5 для анатоксина), однако при введении комплекса белков в тех же дозах индекс эффективности не увеличился и составил 2,8. Заключение. Показано, что максимальный протективный эффект формируется в короткие сроки при использовании комплексной иммунизации двумя рекомбинантными белками OprF и анатоксином в дозах 25 и 50 мкг.

Ключевые слова: Pseudomonas aeruginosa, белок F наружной мембраны, экзотоксин А, анатоксин.

(Для цитирования: Калошин А.А., Леонова Е.И., Солдатенкова А.В., Михайлова Н.А. Исследование протективных свойств рекомбинантного комплекса белка F наружной мембраны и анатоксина Pseudomonas aeruginosa. Becmник PAMH. 2016;71(1):5-10. doi: $10.15690 /$ vramn584)

A.A. Kaloshin, E.I. Leonova, A.V. Soldatenkova, N.A.Mihailova

Mechnikov Research Institute of Vaccines and Sera, Moscow, Russian Federation

\title{
Assessment of Protective Properties of the Recombinant Complex of the Outer Membrane Protein F and the Toxoid of Pseudomonas aeruginosa
}

Pseudomonas aeruginosa induces the complications after burns, injuries, surgical interventions and appears to be one of the main causative agents of nosocomial infections. This pathogen has the high resistance to the antibacterial preparations, therefore the immunoprophylaxis is considered as one of the major approaches to reduce Pseudomonas infection. Objective: The aim of our investigation is to study the protective properties of the recombinant complex of the outer membrane protein $F(\mathrm{OprF})$ and a non-toxic variant of the exotoxin A (toxoid) against Pseudomonas infection. Methods: The recombinant proteins which contained the additional histidine residues were synthesized into Escherichia coli with isopropyl- $\beta$ $D$-thyogalactopyranoside (IPTG). The recombinant proteins were purified by affinity chromatography on Ni-Sepharose. The preparations of recombinant proteins were injected intraperitoneally into the mice. Aluminum hydroxide was used as an adjuvant. For an experimental infection in mice, animals were challenged intraperitoneally by a live virulent culture of $P$. aeruginosa (PA-103 strain). Results: The best protective effect for the complex containing $25 \mu \mathrm{g} \mathrm{OprF} \mathrm{and} 50 \mu \mathrm{g}$ toxoid was identified when we used the double immunization of mice (Index of efficiency of the protective properties in this case was 4.0). Indexes of efficiency of separated recombinant proteins which were injected twice in the same doses were 2.0 for OprF u 2.3 for toxoid. The triple immunization of animals was inefficient for separated recombinant proteins in the same doses. The injection of doses which were lowered twice (12.5 $\mu \mathrm{g}$ for OprF and $25 \mu \mathrm{g}$ for toxoid) resulted in increased survival of mice immunized by individual proteins (indexes of efficiency: 3 for OprF and u 3,5 for toxoid). However when we administered to the complex of proteins with the same doses Index of efficiency was 2.8. Conclusion: It was shown that the maximum protective effect in a short time is achieved by the combination of double immunization and the mixture of the recombinant proteins $\mathrm{OprF}$ and the 25 and $50 \mu \mathrm{g}$ doses of recombinant toxoid.

Key words: Pseudomonas aeruginosa, outer membrane protein $F(O p r F)$, exotoxin A, toxoid.

(For citation: Kaloshin AA, Leonova EI, Soldatenkova AV, Mihailova NA. Assessment Protective Properties of the Recombinant Complex of the Outer Membrane Protein F and the Toxoid of Pseudomonas aeruginosa. Annals of the Russian Academy of Medical Sciences. 2016;71(1):5-10. doi: 10.15690/vramn584) 


\section{Обоснование}

Условно-патогенный микроорганизм Pseudomonas aeruginosa (синегнойная палочка) является одной из основных причин нозокомиальных инфекций. Этот патоген часто вызывает осложнения после ожогов, травм и хирургических вмешательств. Особенностью P. aeruginosa является высокая резистентность практически всех штаммов к большинству применяемых в клинике антибиотиков, что обусловливает трудность терапии синегнойной инфекции в условиях стационара [1-3]. Иммунопрофилактика может рассматриваться как один из приоритетных подходов для эрадикации возбудителя.

В Советском Союзе разработкой вакцин против синегнойной инфекции занимались с середины прошлого века. При этом использовали как инактивированные цельные культуры [4], так и компоненты бактериальных клеток [5]. Эти вакцины не были разрешены для использования в клинике, поскольку содержали массу токсических компонентов. Для устранения нежелательных побочных эффектов в дальнейшем проводились исследования по созданию препаратов, содержащих выделенные и очищенные протективные белки наружной мембраны $[6,7]$. Однако процесс получения очищенных белков трудоемок и сложен. Преодолеть классические технологические трудности позволяет использование генно-инженерных технологий.

В лаборатории протективных антигенов ФГБУ «НИИВС им. И.И. Мечникова» получена и исследована рекомбинантная форма белка F наружной мембраны (OprF) P. aeruginosa. Этот консервативный и иммуногенный белок, участвующий в формировании пор, является чрезвычайно важным для жизнедеятельности бактерии [8]. Показано, что рекомбинантный белок OprF обладает антигенными свойствами и защищает мышей от экспериментальной синегнойной инфекции, вызываемой нетоксигенным штаммом [9].

Одним из наиболее значимых факторов патогенности синегнойной палочки является экзотоксин А, блокирующий синтез белков в клетках млекопитающих. Именно поэтому для эффективной иммунологической защиты организма от $P$. aeruginosa, кроме присутствия антител, связывающихся с поверхностными антигенами микроорганизма, важно достаточное содержание антител для нейтрализации молекул токсина, продуцируемого бактериями [10].

Нами были получены рекомбинантные формы экзотоксина A P. aeruginosa и выявлено, что атоксическая форма (анатоксин) защищала мышей от введения летальных доз функционального рекомбинантного экзотоксина А $P$. aeruginosa [11].

Результаты испытаний протективных свойств рекомбинантных OprF и анатоксина позволили приступить к исследованию их комплексного применения с целью защиты от штамма синегнойной палочки, секретирующего экзотоксин А.

Цель исследования: оценить результаты комплексного применения рекомбинантных $\mathrm{OprF}$ и анатоксина с целью защиты от штамма синегнойной палочки, секретирующего экзотоксин А.

\section{Методы}

\section{Дизайн исследования}

Проведено экспериментальное контролируемое проспективное исследование с целью получения и очистки рекомбинантных белков, оценки их защитных свойств по отдельности и в комплексе при двукратной и трехкратной иммунизации.

\section{Условия проведения}

Исследования проводились в лаборатории протективных антигенов и клинике лабораторных животных ФГБУ «НИИ вакцин и сывороток имени И.И. Мечникова».

\section{Продолжительность исследования}

Исследования проводились с февраля 2014 по май 2015 г.

\section{Методы регистрации исходов}

Синтез рекомбинантных белков проводили путем индукции экспрессии с помощью изопропил- $\beta$-dтиогалактопиранозида (ИПТГ). Очистку рекомбинантного белка осуществляли методом аффинной хроматографии с использованием Ni-сефарозы (Amercham, США) в 8 M буферном растворе мочевины. Биомассу, содержащую рекомбинантный белок, денатурировали в растворе следующего состава: $8 \mathrm{M}$ мочевина; $0,1 \mathrm{M} \mathrm{NaH}_{2} \mathrm{PO}_{4}$; $0,01 \mathrm{M}$ Трис; pH 8,0. Денатурацию осуществляли в течение ночи при комнатной температуре в шейкере (Ecotron, Швейцария) с частотой вращения 120-160 об/мин. Затем с целью удаления нерастворившихся компонентов клеток полученный лизат дважды центрифугировали со скоростью 16000 g при комнатной температуре в течение 20-30 мин. Лизат переносили в колбу, добавляли к нему суспензию $\mathrm{Ni-cефарозы} \mathrm{и} \mathrm{инкубировали} 2$ ч при комнатной температуре в шейкере с легким покачиванием (40 об/мин). Полученную суспензию пропускали через колонку (Віо$\mathrm{Rad}, \mathrm{CША).} \mathrm{С} \mathrm{использованием} \mathrm{хроматографической} \mathrm{си-}$ стемы Biologic LP (Bio-Rad) проводили отмывку сорбента со связавшимся белком. Использовали тот же буфер, который применяли при растворении биомассы, но с $\mathrm{pH}$ 6,3, а затем с рН 5,9. Элюцию проводили аналогичным буферным раствором с $\mathrm{pH} 4,5$.

Для перевода белков в нативное состояние использовали ступенчатый диализ против физиологического раствора, содержащего 6, 4, 2 и 1 М мочевину. На конечном этапе диализ проводили против физиологического раствора без мочевины. Содержание белков определяли при длине волны 280 нм в спектрофотометре Genesys 6 (Thermo Scientific, США). При расчете концентрации рекомбинантных белков использовали следующие коэффициенты экстинкции: 0,7 для OprF и 0,73 для анатоксина, вычисленные в программе OMIGA 2.0 software (http:// www.highbeam.com/doc/1G1-61963309.html). Анализ белковых продуктов проводили в приборе для капиллярного электрофореза QIAxcel Advanced (QIAGEN, Германия).

Рекомбинантные белки для иммунизации животных разводили в физиологическом растворе, добавляли гель гидроксида алюминия в соотношении 1 мг $\mathrm{Al}(\mathrm{OH})_{3}$ на 1 мг белка и проводили сорбцию в течение 12 ч при температуре $4{ }^{\circ} \mathrm{C}$. Препараты в объеме 0,5 мл вводили внутрибрюшинно мышам массой 16-18 г. При индукции экспериментальной инфекции через 2 нед после последней иммунизации животных заражали внутрибрюшинно живой вирулентной культурой $P$. aeruginosa штамма PA-103 в объеме 0,5 мл. Подсчет погибших животных проводили в течение 7 дней.

\section{Этическая экспертиза}

Все работы с животными проводили в соответствии с положениями «Правила проведения работ с использованием экспериментальных животных». 


\section{Статистический анализ}

ЛД 50 вычисляли по формуле Кербера в модификации Ашмарина-Воробьева:

$$
Л Д_{50}=\operatorname{Ig} A-\operatorname{Ig} 4\left(B_{1} / C_{1}+B_{2} / C_{2}+B_{3} / C_{3}\right)-0,5 \text {, }
$$

где $\mathrm{A}$ - максимальная инфекционная доза в опыте, В количество животных, павших в группе, C - первоначальное количество животных в группе.

Стандартную ошибку ЛД ${ }_{50}\left(\mathrm{~S} Л_{50}\right)$ вычисляли по следующей формуле:

$$
\text { SЛ } Д_{50}=\left(\text { ЛД }_{84}-Л_{16}\right): \Delta(2 \times N) \text {, }
$$

где $\mathrm{N}$ - количество животных в группе. ЛД ${ }_{84}$ и ЛД 16 рассчитывали с использованием пробит-анализа [12].

\section{Результаты}

Рекомбинантные белки OprF (Mr 38,9 кДа) и анатоксин (Mr 65,8 кДа) получены в очищенном виде в результа- те аффинной хроматографии в колонках с никельактивированным сорбентом (рис.). На первом этапе очищенные рекомбинантные белки использовали для двукратной иммунизации мышей. Четырем группам животных вводили рекомбинантные белки по отдельности в дозах 25 или 50 мкг. Мыши пятой группы получали смесь двух белков: 25 мкг рекомбинантного OprF и 50 мкг рекомбинантного анатоксина. Интервал между иммунизациями составлял 2 нед. После курса иммунизации животным вводили от 12,5 до 200 млн микробных клеток (мк) живой культуры P. aeruginosa. Животных контрольной группы (мыши той же партии, которым вводили физиологический раствор хлорида натрия) заражали дозами от 6,25 до 100 млн мк. ЛД 50 для группы интактных мышей составила 19 млн мк. В группе животных, иммунизированных рекомбинантным OprF в дозе 25 мкг, ЛД 50 составила 37,9 млн мк; для животных, иммунизированных рекомбинантным анатоксином в дозе 50 мкг, это значение соответствовало

A)

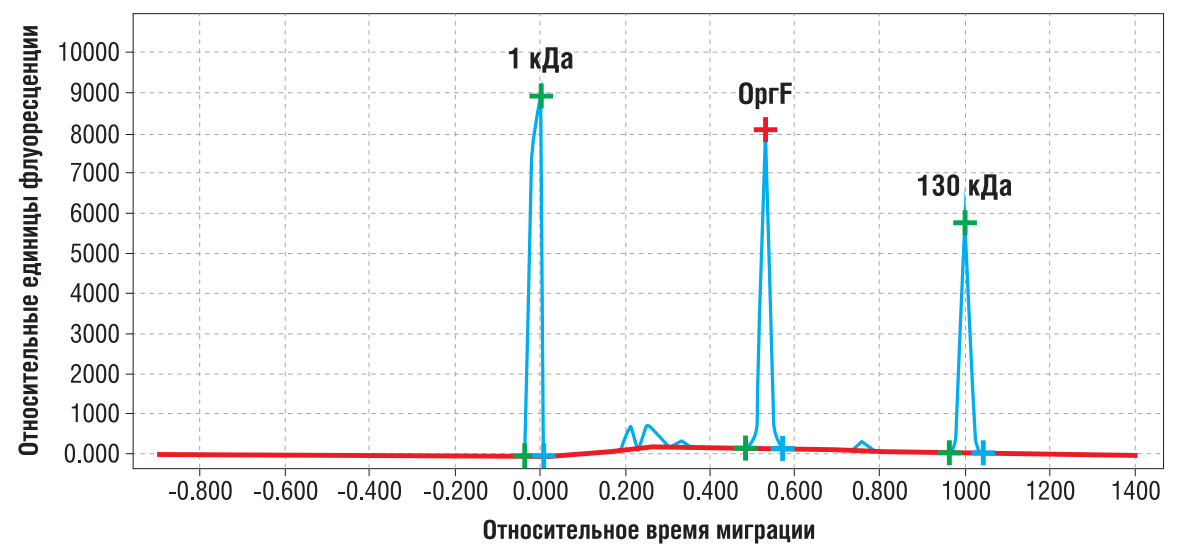

B)

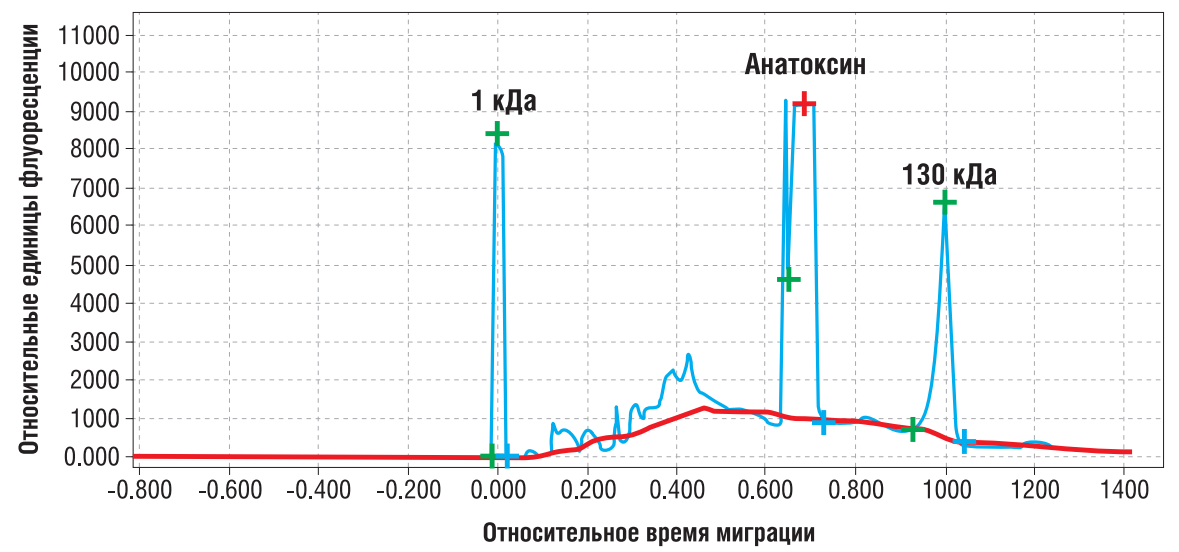

C)

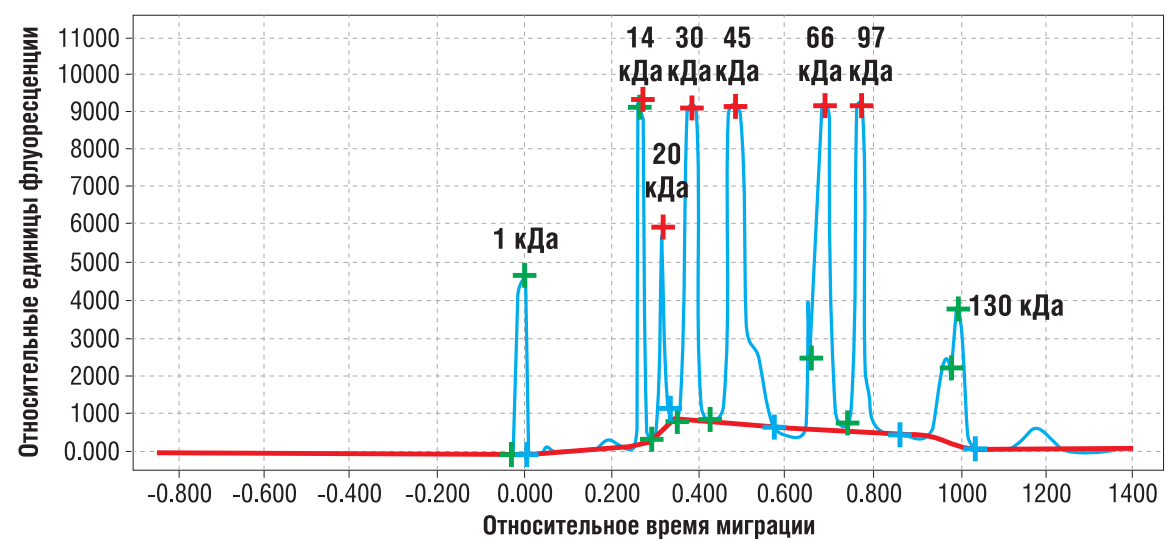

Рис. Анализ белковых продуктов, полученных в результате очистки рекомбинантных белков OprF (А) и анатоксина (B); C — весовой белковый маркер

Примечание. Отмечены размеры фрагментов весового белкового маркера в капилляре С: 14, 20, 30, 45, 66 и 97 кДа. В каждом капилляре присутствовал туннельный маркер: два фрагмента размерами 1 и 130 кДа. 
Таблица 1. Защитные свойства рекомбинантных OprF и анатоксина при двукратной иммунизации

\begin{tabular}{|c|c|c|c|c|}
\hline $\begin{array}{c}\text { Вводимые препараты } \\
\text { (доза) }\end{array}$ & $\begin{array}{c}\text { Доза заражения, } \\
\text { млн мк }\end{array}$ & $\begin{array}{c}\text { Количество мышей павших/ } \\
\text { выживших, n }\end{array}$ & $\begin{array}{c}\text { ЛД }_{50} \text { 土SЛД } \\
\text { млн мк }\end{array}$ & ИЭ \\
\hline \multirow{3}{*}{$\begin{array}{l}\text { OprF }-25 \text { мкг, } \\
\text { гидроксид алюминия }-25 \text { мкг }\end{array}$} & 200 & $10 / 0$ & \multirow{3}{*}{$37,9 \pm 11,3$} & \multirow{3}{*}{2,0} \\
\hline & 50 & $5 / 5$ & & \\
\hline & 12,5 & $2 / 8$ & & \\
\hline \multirow{3}{*}{$\begin{array}{l}\text { OprF }-50 \text { мкг, } \\
\text { гидроксид алюминия }-50 \text { мкг }\end{array}$} & 200 & $10 / 0$ & \multirow{3}{*}{$33 \pm 10,1$} & \multirow{3}{*}{1,7} \\
\hline & 50 & $6 / 4$ & & \\
\hline & 12,5 & $2 / 8$ & & \\
\hline \multirow{3}{*}{$\begin{array}{l}\text { Анатоксин }-25 \text { мкг, } \\
\text { гидроксид алюминия }-25 \text { мкг }\end{array}$} & 200 & $10 / 0$ & \multirow{3}{*}{$28,7 \pm 8,4$} & \multirow{3}{*}{1,5} \\
\hline & 50 & $9 / 1$ & & \\
\hline & 12,5 & $5 / 5$ & & \\
\hline \multirow{3}{*}{$\begin{array}{l}\text { Анатоксин - } 50 \text { мкг, } \\
\text { гидроксид алюминия — } 50 \text { мкг }\end{array}$} & 200 & $9 / 1$ & \multirow{3}{*}{$41,8 \pm 10,6$} & \multirow{3}{*}{2,3} \\
\hline & 50 & $5 / 5$ & & \\
\hline & 12,5 & $2 / 8$ & & \\
\hline \multirow{3}{*}{$\begin{array}{l}\text { OprF }-25 \text { мкг, } \\
\text { анатоксин - } 50 \text { мкг, } \\
\text { гидроксид алюминия }-75 \text { мкг }\end{array}$} & 200 & $6 / 4$ & \multirow{3}{*}{$75,8 \pm 22,1$} & \multirow{3}{*}{4,0} \\
\hline & 50 & $4 / 6$ & & \\
\hline & 12,5 & $2 / 8$ & & \\
\hline \multirow{3}{*}{ Контроль (физ. p-p) } & 100 & $9 / 1$ & \multirow{3}{*}{$19 \pm 5,0$} & \multirow{3}{*}{ - } \\
\hline & 25 & $6 / 4$ & & \\
\hline & 6,25 & $2 / 8$ & & \\
\hline
\end{tabular}

Примечание. ИЭ — индекс эффективности.

41,8 млн мк. Использование рекомбинантного OprF в дозе 50 мкг не выявило преимуществ (ЛД 5033 млн мк). Иммунизация животных 25 мкг рекомбинантного анатоксина оказалась недостаточно эффективной (ЛД 5028,7 млн мк). Наилучший результат (ЛД 5075,8 млн мк) выявлен при комплексной иммунизации обоими рекомбинантными белками (табл. 1).

Далее была проведена трехкратная иммунизация трех групп мышей: рекомбинантным OprF в дозе 25 мкг, рекомбинантным анатоксином в дозе 50 мкг и их комплексом, содержащим те же дозы активных компонентов. Как оказалось, данная иммунизационная схема не была эффективной во всех вариантах. Значения ЛД $_{50}$ для животных иммунизированных групп составили 27,4 млн мк для рекомбинантного OprF, 32,2 млн мк для рекомбинантного анатоксина и 28,7 млн мк для комплекса. ЛД 50 в контрольной группе составила 19 млн мк (табл. 2).

Таблица 2. Защитные свойства рекомбинантных OprF и анатоксина при трехкратной иммунизации

\begin{tabular}{|c|c|c|c|c|}
\hline $\begin{array}{c}\text { Вводимые препараты } \\
\text { (доза) }\end{array}$ & $\begin{array}{c}\text { Доза заражения, } \\
\text { млн мк }\end{array}$ & $\begin{array}{c}\text { Количество мышей павших/ } \\
\text { выживших, n }\end{array}$ & $\begin{array}{c}\text { ЛД }_{50} \pm \text { мЛЛ мк } \\
\underset{50}{ },\end{array}$ & ИЭ \\
\hline \multirow{3}{*}{$\begin{array}{l}\text { OprF }-25 \text { мкг, } \\
\text { гидроксид алюминия }-25 \text { мкг }\end{array}$} & 200 & $10 / 0$ & \multirow{3}{*}{$27,4 \pm 6,6$} & \multirow{3}{*}{1,4} \\
\hline & 50 & $11 / 4$ & & \\
\hline & 12,5 & $2 / 8$ & & \\
\hline \multirow{3}{*}{$\begin{array}{l}\text { Анатоксин }-50 \text { мкг, } \\
\text { гидроксид алюминия }-50 \text { мкг }\end{array}$} & 200 & $10 / 0$ & \multirow{3}{*}{$32,2 \pm 10,1$} & \multirow{3}{*}{1,7} \\
\hline & 50 & $5 / 7$ & & \\
\hline & 12,5 & $4 / 6$ & & \\
\hline \multirow{3}{*}{$\begin{array}{l}\text { OprF }-25 \text { мкг, } \\
\text { анатоксин }-50 \text { мкг, } \\
\text { гидроксид алюминия }-75 \text { мкг }\end{array}$} & 200 & $10 / 0$ & \multirow{3}{*}{$28,7 \pm 7,6$} & \multirow{3}{*}{1,5} \\
\hline & 50 & $9 / 6$ & & \\
\hline & 12,5 & $3 / 7$ & & \\
\hline \multirow{3}{*}{ Контроль (физ. p-p) } & 100 & $10 / 0$ & \multirow{3}{*}{$19 \pm 5,0$} & \multirow{3}{*}{-} \\
\hline & 25 & $7 / 3$ & & \\
\hline & 6,25 & $0 / 10$ & & \\
\hline
\end{tabular}

Примечание. ИЭ - индекс эффективности. 
Таблица 3. Защитные свойства рекомбинантных OprF и анатоксина с уменьшенными дозами при трехкратной иммунизации

\begin{tabular}{|c|c|c|c|c|}
\hline Вводимые препараты (доза) & $\begin{array}{c}\text { Доза заражения, } \\
\text { млн мк }\end{array}$ & $\begin{array}{c}\text { Количество мышей павших/ } \\
\text { выживших, n }\end{array}$ & $\begin{array}{c}\text { ЛД }_{\mathbf{5 0}} \text { 土SЛ } \\
\text { млн мк }\end{array}$ & ИЭ \\
\hline \multirow{3}{*}{$\begin{array}{l}\text { OprF - 12,5 мкг, } \\
\text { гидроксид алюминия - 12,5 мкг }\end{array}$} & 200 & $10 / 0$ & \multirow{3}{*}{$57,4 \pm 11,7$} & \multirow{3}{*}{3} \\
\hline & 50 & $4 / 6$ & & \\
\hline & 12,5 & $0 / 10$ & & \\
\hline \multirow{2}{*}{$\begin{array}{l}\text { Анатоксин - } 25 \text { мкг, } \\
\text { гидроксид алюминия }-25 \text { мкг }\end{array}$} & 50 & $4 / 6$ & \multirow[t]{2}{*}{$66 \pm 13,7$} & \multirow[t]{2}{*}{3,5} \\
\hline & 12,5 & $0 / 10$ & & \\
\hline \multirow{3}{*}{$\begin{array}{l}\text { OprF - 12,5 мкг, } \\
\text { анатоксин - } 25 \text { мкг, } \\
\text { гидроксид алюминия - 37,5 мкг }\end{array}$} & 200 & $12 / 1$ & \multirow{3}{*}{$57,4 \pm 12,4$} & \multirow{3}{*}{2,8} \\
\hline & 50 & $5 / 8$ & & \\
\hline & 12,5 & $2 / 11$ & & \\
\hline \multirow{3}{*}{ Контроль (физ. p-p) } & 100 & $10 / 0$ & \multirow{3}{*}{$19 \pm 5,0$} & \multirow{3}{*}{ - } \\
\hline & 25 & $6 / 4$ & & \\
\hline & 6,25 & $1 / 9$ & & \\
\hline
\end{tabular}

Примечание. ИЭ - индекс эффективности.

На последнем этапе проведена трехкратная иммунизация животных с использованием уменьшенных доз рекомбинантных белков. Для этого мышам первой группы вводили 12,5 мкг рекомбинантного OprF, мышам второй группы - 25 мкг рекомбинантного анатоксина, третьей группы - 12,5 мкг OprF и 25 мкг анатоксина. При данной схеме выявлено существенное увеличение выживаемости мышей, иммунизированных отдельными рекомбинантными белками: в группе иммунизированных рекомбинантным OprF ЛД ${ }_{50}$ составляла 57,4 млн мк, а для животных, иммунизированных рекомбинантным анатоксином, - 66 млн мк. При этом иммунизация двумя белками одновременно по данной схеме не способствовала увеличению защитных свойств (ЛД 50 57,4 млн мк; табл. 3).

\section{Обсуждение}

Ранее показано, что рекомбинантный OprF обладал защитными свойствами от экспериментальной инфекции, вызываемой живой вирулентной культурой P. aeruginosa штамма РА-170015, не секретирующего экзотоксин А [4], а рекомбинантный анатоксин - от рекомбинантного функционального экзотоксина А [7]. Оптимальные иммунизирующие дозы на одно животное (при двукратном введении) составляли 25 мкг OprF и 50 мкг для анатоксина, поэтому их использовали при получении комплексного препарата.

В проведенных экспериментах оба рекомбинантных белка проявили защитные свойства от $P$. aeruginosa штамма РА-103, обладающего высоким уровнем синтеза экзотоксинов. Кроме того, подтверждены оптимальные дозы применяемых белков при двукратной иммунизации. Индексы эффективности (ИЭ) защитных свойств (отношение ЛД 50 для иммунизированных мышей к ЛД ${ }_{50}$ в контрольной группе) составили 2,0 для 25 мкг рекомбинантного OprF и 2,3 для 50 мкг рекомбинантного анатоксина. При комплексной иммунизации обоими рекомбинантными белками ИЭ увеличивался до 4,0 (см. табл. 1).

С целью повышения защитных свойств рекомбинантных белков была апробирована схема трехкратной иммунизации. Однако при использовании ранее подобранных доз, оптимальных для двукратной иммунизации, эта прививочная схема не проявила положительного эффекта.
ИЭ протективных свойств составили 1,4 для OprF, 1,7 для анатоксина и 1,5 для комплекса (см. табл. 2). Вполне вероятно, что дополнительное введение антигенов приводило к иммунодепрессии, поэтому следующим шагом при оптимизации иммунизационных схем стало использование уменьшенных доз рекомбинантных белков при трехкратном введении. Такая схема приводила к существенному увеличению защитных свойств при иммунизации мышей отдельными белками (ИЭ для OprF - 3, ИЭ для анатоксина - 3,5). В то же время комплекс двух белков не показал преимуществ. ИЭ в этой группе составил 2,8 (см. табл. 3).

\section{Заключение}

На основании экспериментальных данных подтверждена эффективность использования комплексной иммунизации двумя рекомбинантными белками, которые способны вызывать иммунные реакции как к поверхностным антигенам микроорганизма, так и к одному из самых серьезных факторов патогенности возбудителя - экзотоксину А. Однако данный факт установлен только при двукратной схеме иммунизации мышей в дозах введения OprF 25 мкг и анатоксина 50 мкг. Возможно, что при трехкратной иммунизации двумя белками низкая эффективность обусловливается излишней антигенной нагрузкой. Именно поэтому в дальнейшем планируется исследование комплекса рекомбинантных OprF и анатоксина с варьированием доз белковых препаратов и адъюванта, а также изучение их влияния на систему приобретенного и врожденного иммунитета.

\section{Источник финансирования}

Работа выполнена при поддержке Программы фундаментальных исследований Президиума РАН «Фундаментальные исследования для разработки биомедицинских технологий» на 2014 год.

\section{Конфликт интересов}

Авторы данной статьи подтвердили отсутствие конфликта интересов, о котором необходимо сообщить. 


\section{ЛИТЕРАТУРА}

1. Falagas ME, Koletsi PK, Bliziotis IA. The diversity of definitions of multidrug-resistant (MDR) and pandrug-resistant (PDR) Acinetobacter baumannii and Pseudomonas aeruginosa. J Med Microbiol. 2006;55(12):1619-1629. doi: 10.1099/jmm.0.46747-0

2. Strateva T, Yordanov D. Pseudomonas aeruginosa - a phenomenon of bacterial resistance. J Med Microbiol. 2009;58(9):1133-1148. doi: 10.1099/jmm.0.009142-0.

3. Бобровничий В.И. Современные подходы к диагностике и лечению синегнойной инфекции у больных муковисцидозом // Медицинский журнал. - 2012. - №1. - C. 4-9. [Bobrovnichii VI. Modern approaches to diagnosis and treatment of Pseudomonas aeruginosa infection in a patient with cystic fibrosis. Meditsinskii zhurnal. 2012;1:4-9. (In Russ).]

4. Мороз А.Ф. Применение поливалентной вакцины с защитным эффектом против Pseudomonas aeruginosa / Сб. материалов Всесоюзной конференции по ранам и раневой инфекции. - M.; 1977. С. 73-74. [Moroz AF. Primenenie polivalentnoi vaktsiny s zashchitnym effektom protiv Pseudomonas aeruginosa. (Conference proceedings) Sb. materialov Vsesoyuznoi konferentsii po ranam i ranevoi infektsii. Moscow; 1977. p. 73-74. (In Russ).]

5. Станиславский Е.С. и др. Бесклеточная псевдомонас-вакцина. Лабораторные испытания эффективности экспериментальных псевдомонас-вакцин // Журнал микробиологии, элидемиологии и иммунологии. - 1982. - №10. - С. 25-29. [Stanislavskii ES, et al. Beskletochnaya psevdomonas-vaktsina. Laboratornye ispytaniya effektivnosti eksperimental'nykh psevdomonas-vaktsin. Zhurnal mikrobiologii, epidemiologii i immunologii. 1982;10:25-29. (In Russ).]

6. Макаренко Т.А., Станиславский Е.С. Иммунологическое изучение белков клеточной стенки Pseudomonas aeruginosa // Журнал микробиологии, эпидемиологии и иммунологии. - 1996. - №2. - C. 7-9. [Makarenko TA, Stanislavskii ES. Immunologicheskoe izuchenie belkov kletochnoi stenki Pseudomonas aeruginosa. Zhurnal mikrobiologii, epidemiologii $i$ immunologii. 1996;2:7-9. (In Russ).]
7. Kim DK, Kim JJ, Kim JH, et al. Comparison of two immunization schedules for a Pseudomonas aeruginosa outer membrane proteins vaccine in burn patients. Vaccine. 2000;19(9-10):1274-1283. doi:10.1016/S0264-410X(00)00235-8

8. Krishnan S, Prasadarao NV. Outer membrane protein A and OprF Versatile roles in Gramnegative bacterial infections. FEBS Journal. 2012;279(6):919-931. doi: 10.1111/j.1742-4658.2012.08482.x.

9. Калошин А.А., Гатыпова Е.В., Михайлова Н.А. Получение рекомбинантных форм белка $\mathrm{F}$ наружной мембраны (OprF) Pseudomonas aeruginosa и исследование их иммуногенных свойств // Биотехнология. - 2011. - №2. - С. 74-84. [Kaloshin AA, Gatypova EV, Mikhailova NA. Obtaining of Recombinant Forms of Outer Membrane Protein F from Pseudomonas aeruginosa and Assessment of their Immunogenic Properties. Biotekhnologiia (Mosc.). 2011;2:74-84. (In Russ).]

10. Вертиев Ю.В., Бродвинова Н.С., Мороз А.Ф. Экзотоксин A Pseudomonas aeruginosa и его роль в патогенезе синегнойной инфекции // Журнал микробиологии эпидемиологии и иммунологии. - 1981. - №2. - С. 13-19. [Vertiev YV, Brodvinova NS, Moroz AF. Ekzotoksin A Pseudomonas aeruginosa i ego rol' v patogeneze sinegnoinoi infektsii. Zhurnal mikrobiologii epidemiologii i immunologii. 1981;2:13-19. (In Russ).]

11. Калошин А.А., Исаков М.А., Михайлова Н.А., Вертиев Ю.В. Получение рекомбинантной атоксической формы экзотоксина A Pseudomonas aeruginosa // Бюллетень экспериментальной биологии и медицины. - 2012. - Т. 154. - №9. - С. 330-335. [Kaloshin AA, Isakov MA, Mikhailova NA, Vertiev JV. Preparation of Recombinant Atoxic Form of Exotoxin A from Pseudomonas Aeruginosa. Bull Exp Biol Med. 2013;154(3):346-350.] doi: 10.1007/ s10517-013-1947-1

12. Ашмарин И.П., Воробьев А.А. Статистические методы в микробиологических исследованиях. - Л.: Медицинская литеpamypa; 1962.180 c. [Ashmarin IP, Vorob'ev AA. Statisticheskie metody v mikrobiologicheskikh issledovaniyakh. Leningrad: Meditsinskaya literatura; 1962. 180 p. (In Russ).]

\section{КОНТАКТНАЯ ИНФОРМАЦИЯ}

Калошин Алексей Алексеевич, кандидат биологических наук, ведущий научный сотрудник лаборатории протективных антигенов ФГБУ «НИИ вакцин и сывороток им. И.И. Мечникова» Адрес: 105064, Москва, Малый Казенный переулок, д. 5а, тел.: +7 (495) 916-25-87, e-mail: alex-k-1973@yandex.ru

Леонова Евгения Игоревна, младший научный сотрудник лаборатории протективных антигенов ФГБУ «НИИ вакцин и сывороток им. И.И. Мечникова»

Адрес: 105064, Москва, Малый Казенный переулок, д. 5а, тел.: +7 (495) 916-25-87, e-mail: evgeniya-leonova@mail.ru

Солдатенкова Алёна Владимировна, научный сотрудник лаборатории протективных антигенов ФГБУ «НИИ вакцин и сывороток им. И.И. Мечникова»

Адрес: 105064, Москва, Малый Казенный переулок, д. 5а, тел.: +7 (495) 916-25-87, e-mail: lesic7@yandex.ru

Михайлова Наталья Александровна, доктор медицинских наук, профессор, заведующая лабораторией протективных антигенов, заместитель директора по научной работе ФГБУ «НИИ вакцин и сывороток им. И.И. Мечникова» Адрес: 105064, Москва, Малый Казенный переулок, д. 5а, тел./факс: +7 (495) 917-56-30, e-mail: n_michailova@inbox.ru 